\title{
An Evaluation of the Leadership Role Played by the Head of School in the Delivery of Quality Education in Zimbabwean Day Secondary Schools: A Case Study of Zvishavane in Zimbabwe
}

\author{
Wilard Nyathi ${ }^{*}$, Caxton Shonhiwa ${ }^{2}$ \\ ${ }^{1}$ Dean: Faculty of Education: AMADI University: Swaziland \\ ${ }^{2}$ Senior Lecturer: Faculty of Commerce: Zimbabwe Open University
}

*Corresponding Author: Wilard Nyathi, Dean: Faculty of Education: AMADI University: Swaziland

\begin{abstract}
Quality education is a critical phenomenon for the provision of quality human resources in any country. Quality education focuses on learning which strengthens the capacity of children to act progressively on their own behalf through the acquisition of knowledge in useful skills. Quality in terms of school products implies school graduates who are not just literate or numerate, but graduates who add value to their families, communities as well as nation through the knowledge, skills and morals they acquired from the school system. In Zimbabwe the parents, government and employers place a very high premium on the quality of education that schools provide to their learners. Certain schools are shunned because of their perceived low standards and yet others are sought after by many parents and students due to the quality of learning perceived to obtain in them. Quality therefore is about high standards of achievement by pupils in all spheres. Quality does not come about like manna from heaven. It is brought about in an organisation deliberately through the leadership process. This article draws on a quantitative enquiry on the role played by heads as leaders of schools in the delivery of quality education in Zimbabwean Secondary schools. The study adopted the descriptive survey design. The target population included all secondary school teachers in Zvishavane District which has a secondary teacher population of about 1500 teachers. Random sampling was used to arrive at a sample of 200 respondents who were made up of 120 males and 80 females. All the information was collected through a questionnaire which had both close-ended and open-ended questions. Descriptive statistical analysis was used to interpret the data. The study revealed that heads did not encourage attendance by pupils to all lessons, there was inadequate provision of stationary and learning equipment and that supervision of learning was not adequately done by the heads. The study also reveals that heads were not results focused in their operations. The study recommends that heads of schools should be equipped with skills and knowledge in the field of leadership and management so that they promote quality education in their schools. Heads should also prioritise supervision of instruction and provision of adequate teaching/learning materials.
\end{abstract}

Key terms: Head, circuit, quality education delivery, teachers, secondary school

\section{INTRODUCTION}

In Zimbabwe, prior to independence, one of the major grievances of African Rhodesians was that, secondary schooling was harshly restricted by a selection process at Grade 7 (Robins and Coulter 2012). Thus, in 1976 when $70 \%$ of children were able to attend primary school, only $23 \%$ of Grade 7 pupils could proceed to secondary (Zvobgo 1986). The new government made an early decision and in mid-year announced that from January 1981 every child who finished Grade 7 could automatically proceed to Form 1, regardless of examination results (Kanyenze et.al 2011). Places would be available for all. From 22,201 in 1980 the Form 1 intake nearly quadrupled in 1981 to 83,491 (Chivore 1996). With this policy being continued from year to year, by 1986 the secondary school population surged to over half a million (Smith 1986).

As Ndlovu (1996) observed, the logical consequence of such rapid expansion was concentration on quantity at the expense of quality. This gave rise to shortages of classrooms, textbooks, equipment as well as of teachers. The government through the assistance of the international community invested in the infrastructural development of all the new rural secondary schools to cater for the new high enrolments (World Bank 1990). Teacher training colleges and universities churned out teachers to 
man the new schools. There was a heavy presence of untrained teachers. However, as Moyo and Mumbengegwi (2005) state, by $199525 \%$ of 27,458 teachers in the secondary school were untrained but nearly half of that $25 \%$ were university graduates without teaching certificates. By 2005 the Zimbabwean school system was manned by $95 \%$ qualified teachers with temporary teachers largely found in the rural areas (Shoko 2011). In spite of the huge investments injected into the secondary school sector as a result of the expansion after 1980, there are complaints about the efficiency of the rural secondary schools (Ncube 2004).

Quality indicators include high transition rates from one form to the next, high pass rates at public examinations, teacher pupil ratios, pupil-textbook ratios, availability of proper classrooms including specialist rooms and the adequacy of learning materials and equipment (Liston 2012). It is on account of the above information that the study set out to explore the role played by the head of the school in the delivery of quality education in the Zimbabwean Secondary Schools.

\section{LITERATURE REVIEW}

According to Hay (2005) quality of education is the total effect of the features of the process, or service on its performance or the customers or clients' perception of that performance. It is not a feature of a finished product or service, but involves a focus on internal processes and outputs, and includes the reduction of waste and the improvement of the productivity. This view of quality applied to education implies that quality cannot be measured by looking at the outputs, which are the examination results. Rather, the internal efficiency of the school system, which controls wastages in form of school dropouts, repetition rates, or wastage ratios, is a more appropriate measure of the quality of education.

Liston (2012) argues that quality is related more to the relevance and value of each institution's mission, purpose, goals and objectives, and the achievement of identified outcomes. What emerges from this view is that quality can be more effectively assessed by looking at what happens in the school, rather than broad policy parameters. This observation is congruent with Heneveld's (2012) argument that while most of the national reform efforts seem to assume that a national policy and the delivery of inputs to schools will ensure quality of education, the impacts on student of efforts that ignore the internal trends within the school is usually limited. This is true as the school is where educational objectives are operationalized and the success or lack of it must be analysed at this level.

According to Sallis (2005) quality is what is good for the school and its students. Huxtable (2014) defines quality as the satisfaction of agreed customer's requirements. If school system's internal efficiency is low resulting in low pass rates, high dropout rates, and low survival rates, that school system is not able to help its students, their parents and the community who constitute the clients. As Wadworth (2012) observes, with a low internal efficiency the school system would be unpopular and have no sustainable market, nor will its graduates fit well in the job market. Thus, low internal efficiency compromises the quality of education offered.

According to Whitaker (2008) quality is relative to resources, which implies that even rural secondary schools, which have limited resources, can still achieve quality of education within the context of available resources. Cotton (2011) posits that in an educational setting, the transformation of culture is a function of staff motivation and academic leadership in an environment that is student centred. This notion implies that quality is not determined exclusively by material inputs; rather human beings must be willing and be able to deliver the quality. Leadership charts the direction of the quality to be pursued in order to satisfy the student (Smit and Cronje 2007). In the school set-up, the head is at the centre of internal efficiency and his/her role determines the existence or non-existence of quality in the school. The notions held by Sallis (2006) and Cotton (2011) coincide with those of Liston (2009) who stresses that a quality approach focuses on identifying client needs; developing and tapping the full potential of staff and improving processes. What transcends all these views, is the fact that quality seems to be embodied in people and what they do rather than in a product that goes out to the market.

As Steyn (2012) argues, one necessary condition for an organisation to satisfy customer needs is that there should be leadership with a vision to direct it. Quality requires outstanding leadership (Barry 2009). In the context of rural secondary schools the leadership that ought to drive the quality vision should come from the head. Creech (2010) posits that leadership is learnt from others, through study 
and experience. This notion is in line with the view held by Steyn (2012) that commitment of leadership infiltrates all levels of the schooling. There is, therefore, need for leadership to train people at all levels of the school to enable them to participate actively and meaningfully.

\section{Statement of the Problem}

The study sought to explore the role played by the head of school in the delivery of quality education in Zimbabwean secondary schools.

\subsection{Purpose of the Study}

The study sought to establish the role played by the head of schools in delivery of quality in Zimbabwean secondary schools. The study also sought to come up with suggestions to enhance the management of quality of education in Rural Day Secondary Schools in Zimbabwe.

\subsection{Research Questions}

The study sought to provide answers to the following sub-problems.

1. Are heads of schools conscious about the need to promote quality at their schools?

2. How can school heads promote quality education in their schools?

3. What are the challenges faced by heads in the delivery of quality?

4. What improvements can be effected to promote quality education in schools?

\subsection{Significance of the Study}

Investment in education in Zimbabwe occurs against a backdrop of scarce resources, and thus an insight into the internal efficiency of the school system helps employ resources to the best benefit of both the students and the nation. It was hoped that the study would reveal trends in the internal efficiency of Rural Day Secondary Schools in Zimbabwe as well as factors affecting it (quality) which would in turn help schools, the Ministry of Primary and Secondary Education, and other stakeholders to improve educational provision and reduce wastages.

\subsection{Limitations of the Study}

In view of the same size of the sample and sub-samples used, the findings of this study therefore, will have limited generalizability. It has to be pointed out that perceptions about an issue are essentially subjective and cannot be measured accurately. Moreover, since feelings may vary in intensity, what may be interpreted by one individual may be interpreted differently by another. In other words, attitudes have no universally recognised and accepted scales of measurements and measures used in this study cannot be considered to be very accurate.

\subsection{Delimitations of the Study}

The study was concerned with the role played by school heads in the delivery of quality education in Zimbabwean Day Secondary Schools. The sample comprised of 200 teachers from Zvishavane District. Heads, Education Officers, parents and students were not the concern of this study in terms of how they perceive the role of heads in the delivery of quality.

\section{RESEARCH METHOdOLOGY}

The study employed the quantitative methodology. The quantitative methodology was chosen for its ability to enable this study's findings to be generalised to other circuits (Dlumberg 2008). The study settled for the survey research design. The population comprised of 1500 teachers from the district. The simple random sampling was used to come up with a sample of 200 teachers because it permitted every teacher to have an equal chance of participating in the study (Kumar 2009). The researchers used a questionnaire which largely had close-ended questions and two open-ended questions. Closeended questions enabled the researchers to collect pre-determined respondents' opinions regarding the studied phenomena (Anderson 2011). The researchers were able to get the actual situation on the ground regarding the role of heads in the delivery of quality education from the respondents' openended response.

\subsection{Data Collection and Analysis}


An Evaluation of the Leadership Role Played by the Head of School in the Delivery of Quality Education in Zimbabwean Day Secondary Schools: A Case Study of Zvishavane in Zimbabwe

Data was gathered by means of a questionnaire which was largely made up of close-ended questions and few open-ended questions. The questionnaire was chosen as Lawrence (2005) observes, because it has the ability to reach many respondents who live at widely dispersed addresses and preserves anonymity which encourages greater honesty. However, Anderson (2011) argues that a questionnaire generally has low response rate and is inflexible in that it does not allow ideas or comments to be explored in-depth and many questions may remain unanswered. The researchers personally distributed the questionnaires to the schools where the respondents worked. The same method was used to collect the completed questionnaires. Data generated through the questionnaire produced descriptive statistics around the variables under study. These statistics were computed and inferential implications from them derived.

\subsection{Findings and Discussion}

The study set out to explore the role played by school heads in the delivery of education in Zimbabwean Rural Secondary Schools. This section is presented in two parts, namely, presentation of data and discussion.

\subsection{Presentation of Data}

Table1. Composition of sample by gender $(N=200)$

\begin{tabular}{|l|l|l|}
\hline Sex & Frequency & Percentage \\
\hline Male & 120 & 60 \\
\hline Female & 80 & 40 \\
\hline Total & $\mathbf{2 0 0}$ & $\mathbf{1 0 0}$ \\
\hline
\end{tabular}

As table 1 reveals, $60 \%$ of the respondents were male and $40 \%$ female. The datum was considered statistically significant to the extent that it confirmed the hypothesis that more teachers in Zimbabwean Rural Secondary Schools are of male gender. For example, Ndlovu (2012) on a study of gender composition of teachers in Binga District Rural Secondary Schools found that $72 \%$ of the teachers were male.

Table2. Composition of respondents by approximate age $(N=200)$

\begin{tabular}{|l|l|l|}
\hline Age in years & Frequency & Percentage \\
\hline Below 30 & 100 & 50 \\
\hline $31-40$ & 70 & 35 \\
\hline $41-50$ & 30 & 15 \\
\hline 51 and above & 0 & 0 \\
\hline Totals & $\mathbf{2 0 0}$ & $\mathbf{1 0 0}$ \\
\hline
\end{tabular}

The information on table 2 above shows that the majority of the respondents (85\%) are below 40 years. Those above 40 years constitute an insignificant $15 \%$ of the sample.

Table3. Composition of respondents by professional qualifications $(N=200)$

\begin{tabular}{|l|l|l|}
\hline Category & Frequency & Percentage \\
\hline Certificate in education & 20 & 10 \\
\hline Diploma in Education & 160 & 80 \\
\hline Graduate Diploma in Education & 0 & 0 \\
\hline Bachelor of Education & 20 & 10 \\
\hline Totals & $\mathbf{2 0 0}$ & $\mathbf{1 0 0}$ \\
\hline
\end{tabular}

Table 3 above shows that the majority of respondents were in possession of the Diploma in Education qualification (80\%) a few held the Certificate in Education (10\%) and the Bachelor of Education Degree (10\%) qualifications respectively. As Watson (2008) argued, both academic and professional qualifications contribute towards the way teachers define quality issues in an education institution.

Table4. School head promotes attendance of lessons by all pupils all the times $(N=200)$

\begin{tabular}{|l|l|l|}
\hline Response category & Frequency & Percentage \\
\hline Agree & 90 & 45 \\
\hline Disagree & 110 & 55 \\
\hline Undecided & 0 & 0 \\
\hline Totals & $\mathbf{2 0 0}$ & $\mathbf{1 0 0}$ \\
\hline
\end{tabular}


An Evaluation of the Leadership Role Played by the Head of School in the Delivery of Quality Education in Zimbabwean Day Secondary Schools: A Case Study of Zvishavane in Zimbabwe

Table 4 above shows that $55 \%$ of the respondents felt that their heads were not doing enough to encourage pupils to attend to all lessons in all subject areas. Those who indicated that their heads were promoting high attendance were $45 \%$ of the sample.

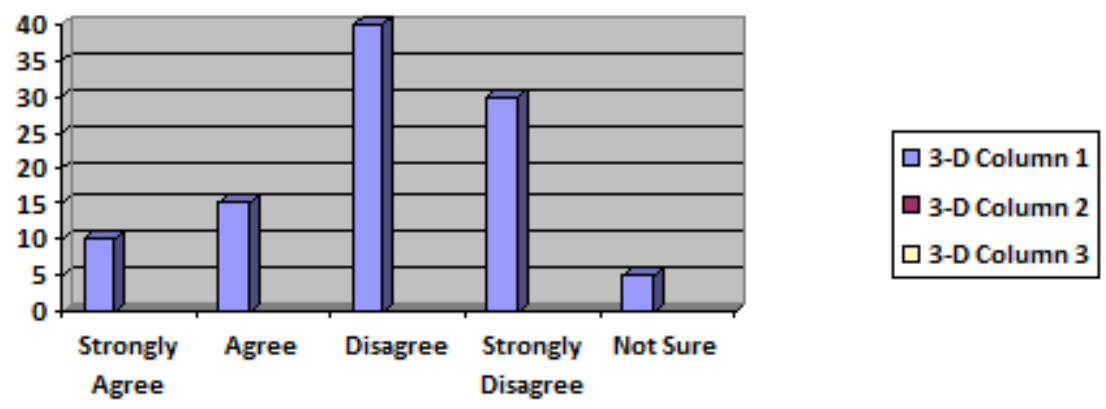

Figure1. Head priorotises procurement of learning materials and equipment on school budgets $(N=200)$

The majority of teachers in figure $1(70 \%)$ indicated that heads did not prioritise the procurement of learning materials and equipment on school budgets. Those who felt the heads prioritised materials and various forms of equipment during school budgeting constituted $25 \%$ of the respondents. Those who were not sure about how the budgets were worked out were $5 \%$ of the respondents.
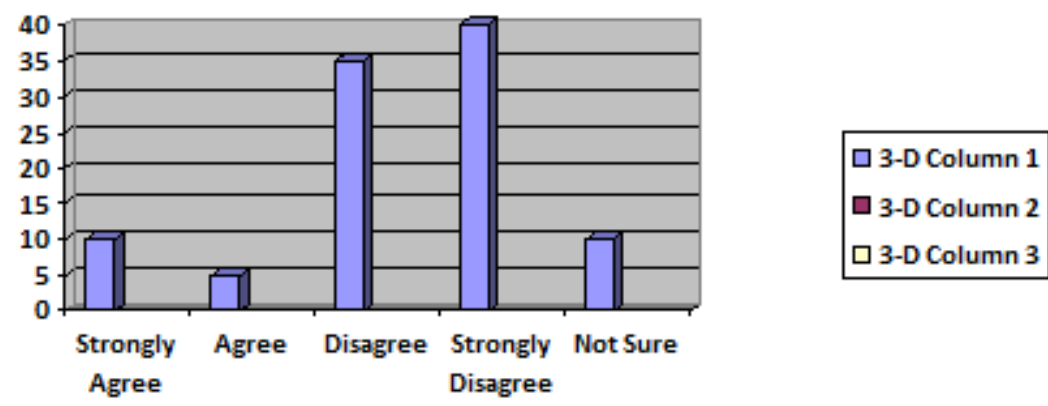

Figure2. The head has a vision of hard work towards high pass rates and shares his / her vision with teachers $(N=200)$

The information on figure 2 above reveals that an overwhelming majority of the respondents (75\%) indicated that their heads did not possess a shared vision of hard work towards high pass rates in their schools. An insignificant number of respondents (15\%) felt their heads had a shared vision of hard work. Those who were not sure about this statement constituted $10 \%$ of the respondents.

Table5. School head works very hard to provide adequate classrooms and specialist rooms $(N=200)$

\begin{tabular}{|l|l|l|}
\hline Category of responses & Frequency & Percentage \\
\hline Always & 2 & 10 \\
\hline Sometimes & 5 & 25 \\
\hline Often & 3 & 15 \\
\hline Never & 10 & 20 \\
\hline Totals & $\mathbf{2 0}$ & $\mathbf{1 0 0}$ \\
\hline
\end{tabular}

Table 5 above shows that only $10 \%$ of the respondents believed that their heads worked very hard to provide adequate classrooms and specialist rooms. A significant (50\%) felt that the heads were not concerned about the provision of adequate rooms for learning and teaching.

Table6. School head discourages drop-outs all the time $(N=200)$

\begin{tabular}{|l|l|l|}
\hline Response category & Frequency & Percentage \\
\hline Agree & 6 & 30 \\
\hline Disagree & 13 & 65 \\
\hline Not sure & 1 & 5 \\
\hline Totals & $\mathbf{2 0}$ & $\mathbf{1 0 0}$ \\
\hline
\end{tabular}


The information on table 6 shows that the majority of respondents $(65 \%)$ felt that their heads were not discouraging pupils from dropping out of school. Those who thought they were discouraging pupils constituted $30 \%$ of the respondents, whilst $5 \%$ were not sure about the question.

The questionnaire had two open-ended questions which bolstered data from the close-ended questions. The first question sought to find out from the teachers whether their heads put the school's clients at the centre of its operations. The majority of the teachers thought that their heads were preoccupied with administrative chores at the expense of clients. They also thought that their heads had misplaced conceptions about who the major clients of the school were. Most of the time, heads thought the major clients of the school were Education Officers and the Provincial Education Director.

The second question sought to find out from the respondents on whether their heads carried out supervision sessions to promote quality education in the schools. The majority of the teachers felt that heads' supervision schedules were sporadic and meant to fulfil the supervision task as the teachers did not benefit much from these sessions.

\section{DISCUSSION}

Information from the study reveals that heads were not doing enough to encourage pupils to attend to school on a sustained basis. As Hey (2005) argues, attendance of pupils on a consistent and sustained way is one of the critical indicators of quality in a school situation.

Findings also reveal that the heads do not prioritise the procurement of learning materials and equipment when making school budgets. This information contradicts Liston's (2012) findings where he argued that adequacy of learning materials and equipment promoted quality education.

The study also shows that most of the heads did not possess a shared vision of hard work towards high pass rates in their schools. As Steyn (2012) argues, one necessary condition for an organisation to satisfy processes and products is that there should be leadership with a vision to direct.

Data also shows that the heads were not concerned about the provision of adequate rooms for learning and teaching both ordinary and specialist classrooms. Classrooms are fundamental for quality education as Huxtable (2011) states, availability of proper classrooms including specialist rooms is key to quality education.

Findings also reveal that school heads were not discouraging pupils from dropping out of school before they completed their studies. As Cotton (2011) argues, there can be no talk about quality without high transition rates from one form to the next. When pupils drop out of school, they constitute wastage.

Findings also reveal that heads are not very clear about who constitutes their key clients in the school situation. As Barry (2009) observes, one necessary condition for achievement of quality in an organisation is to identify major clients and then satisfy them.

Data also reveal that heads' supervision sessions did not benefit the teachers in the promotion of quality education. Creach (2010) argues that commitment of leadership infiltrates all levels of schooling.

\section{CONClusion}

Given the background of the above findings, the researchers make the following conclusions:

- Heads are not doing enough to discourage high drop-out rates in their schools.

- In most of the schools. Heads do not prioritise the procurement of learning materials and equipment for teaching and learning.

- Most heads do not have a shared vision of hard work towards high pass rates in the schools.

- There are no adequate ordinary classrooms and specialist rooms in most of the schools.

- Most of the heads do not work towards client satisfaction as they have no clear conceptualisation of who their key clients are. 
An Evaluation of the Leadership Role Played by the Head of School in the Delivery of Quality Education in Zimbabwean Day Secondary Schools: A Case Study of Zvishavane in Zimbabwe

- The supervision sessions that heads undertake do not significantly benefit the teachers.

\section{RECOMMENDATIONS}

In light of the findings of this study, the researchers would like to make some recommendations.

- Heads should come up with strategies to discourage pupils from dropping out from school and make sure that all pupils who join at Form one are shepherded until they go through their secondary education.

- School budgets ought to prioritise procurement of learning materials and equipment instead of peripheral activities.

- Heads as leaders within their schools should have shared visions about hard-work towards high pass rates so that all in the schools will work towards producing high pass rates.

- School heads should deliberately work towards creation of adequate classroom space so that pupils learn in conducive environments.

- Heads should satisfy the needs of their clients so that all clients feel part of the school and contribute towards quality education.

- Supervision of teaching should be professionally undertaken so that it benefits the teachers so that they can perform better for the pupils.

\section{REFERENCES}

[1] Anderson, L. (2011). Research in education. Sydney: Allen Unwin.

[2] Barry, T. J. (2009). Management for excellence through quality. Winsconsin: ASQC Quality Process.

[3] Blumberg, B. (2008). Business research methods. London: Routledge.

[4] Chivore, B. R. S. (1996). Educational administration and management: A methodological handbook for primary school heads in Zimbabwe. Harare: University of Zimbabwe.

[5] Cotton, K. (2011). Applying total quality management principles to secondary education. Portland: Northwest Regional Educational Laboratory.

[6] Creech, B. (2010). The five pillars of TQM: How to make total quality management work for you. New York: Truman Talley Books / Plume.

[7] Heneveld, S. (2012). Quality in the school system. London: Longman.

[8] Hoy, C. (2005). Improving quality in education. London: Falmer Press.

[9] Huxtable, N. (2014). Small business total quality. London: Kogan Page.

[10] Kanyenze, et.al (2011). Beyond the enclave: Towards a pro-poor and inclusive development strategy for Zimbabwe. Harare: Weaver Press.

[11] Lawrence, S. (2005). An introduction to curriculum research and development. London: Butler and Turner Limited.

[12] Liston, C. (2012). Managing quality standards. Burckingham: Open University Press.

[13] Moyo, S. and Mumbengegwi, B. (2005). Quantity versus quality: Education for all in Zimbabwe. Harare: $\mathrm{ZPH}$.

[14] Ncube, N. (2004). Managing the quality of education in Zimbabwe: The internal efficiency of rural day secondary schools. Pretoria: UNISA.

[15] Ndlovu, S. (2012). Gender composition of Binga District day secondary school teachers. Harare: ZPH.

[16] Ndlovu, V. I. (1996). Uppertops: A curse of a blessing in Zimbabwe's quest for access to secondary education. Harare: University of Zimbabwe.

[17] Robbins, S. P and Coutler, M. (2012). Management. New Delhi: Prentice Hall.

[18] Sallis, E. (2006). Financing education in Zimbabwe. Harare: University of Zimbabwe.

[19] Smith, D. (1986). Quality in the school: Whose concern is it? Harare: Longman.

[20] Steyn, G. M. (2012). Focusing on guiding principles of quality to redesign educational institutions. South African Journal of Education, 21 (1): 17-24.

[21] Wadsworth, H. M. (2012). Modern methods for quality control and improvement. New York. John Wiley and Sons.

[22] Whitaker, P. (2008). Managing change in schools. Buckingham: Open University Press. 
An Evaluation of the Leadership Role Played by the Head of School in the Delivery of Quality Education in Zimbabwean Day Secondary Schools: A Case Study of Zvishavane in Zimbabwe

[23] World Bank (1990). Implementing educational policies in Zimbabwe. Washington DC: Thee World Bank.

\section{AUTHORS' BIOGRAPHIES}

Wilard Nyati (Dr): He is a Senior Lecturer and National Programme Leader for the Master of Education in Educational Management in the Faculty of Arts and Education at the Zimbabwe Open University. $\mathrm{He}$ is a $\mathrm{PhD}$ holder in Educational Management. He has published 20 papers with peer reviewed journals.

Caxton Shonhiwa. (Dr): He is a Senior Lecturer and National Programme Leader for the Bachelor of Education in Educational Foundations in the Faculty of Arts and Education at the Zimbabwe Open University. He is a PhD holder in Management Education, Training, Development and Evaluation. He has published several papers with peer reviewed journals.

Citation: Wilard Nyathi, Caxton Shonhiwa. "An Evaluation of the Leadership Role Played by the Head of School in the Delivery of Quality Education in Zimbabwean Day Secondary Schools: A Case Study of Zvishavane in Zimbabwe" International Journal of Humanities Social Sciences and Education (IJHSSE), vol 7, no. 10, 2020, pp. 51-58. doi: https://doi.org/10.20431/2349-0381.0710006.

Copyright: (C) 2020 Authors. This is an open-access article distributed under the terms of the Creative Commons Attribution License, which permits unrestricted use, distribution, and reproduction in any medium, provided the original author and source are credited. 